\title{
DESPLIEGUES VISUALES EN INSTALACIONES RELIGIOSAS DE LOS ANDES DEL SUR. UNA REFLEXIÓN DESDE EL ARTE RUPESTRE COLONIAL Y LA ETNOHISTORIA
}

\author{
VISUAL DISPLAYS IN RELIGIOUS INSTALLATIONS OF THE SOUTHERN \\ ANDES. A REFLECTION FROM THE PERSPECTIVE OF COLONIAL ROCK \\ ART AND ETHNOHISTORY
}

\author{
Marco Arenas $^{A} \&$ María Carolina Odone ${ }^{B}$
}

\begin{abstract}
El objetivo de este trabajo es presentar evidencias de prácticas andino colonial de pintar en muros de iglesias y capillas situadas en espacios rurales de los Andes del sur. Interesa reflexionar cómo esas prácticas se relacionarían con el sistema del arte rupestre, reconociéndose que ellas estarían alumbrando sobre procesos de semiosis o comunicación de sociedades dominadas, las que están explorando espacios de significación con y desde códigos visuales propios. Siendo entonces las pinturas de muros de iglesias y capillas claras señales de la persistencia de lenguajes plásticos que responden a la cultura propia, pese a los profundos cambios y transformaciones que vivieron las poblaciones andinas luego de la conquista hispana del siglo XVI.

Palabras clave: arte rupestre, semiosis, iglesias y capillas cristianas, Andes del sur.
\end{abstract}

The aim of this work is to present evidence of the Andean colonial practice of painting the walls of rural churches and chapels of the Southern Andes, and to reflect on how those practices are related with the system of rock art, recognizing that these works illuminate semiotic or communication processes of subjugated societies, which are exploring spaces of signification with and from their own visual codes. These church and chapel wall paintings are clear signs of the persistence of the plastic languages belonging to those societies, despite the deep changes and transformations those Andean populations underwent as a result of the Spanish conquest in the 16th century.

Keywords: rock art, semiosis, christian churches and chapels, Southern Andes.

\section{EL ARTE RUPESTRE EN LOS ANDES DEL SUR. UNA BREVE SIINTESIS}

Hacia el periodo de contacto andino hispano en los Andes del sur, en muchos sitios coexisten estilos de arte rupestre local con influencia del Tawantinsuyu (Troncoso 2004; Hernández 2006; González 2015). Otros, presentan la impronta exclusiva de los inkas, instalando algunos significantes de orientación centralizada (Sepúlveda 2004, 2008; Hernández 2006; Hostnig 2006; Berenguer 2013), estos últimos con una fuerte tendencia a la ortogonalidad (Vilches \& Uribe 1999; Sepúlveda 2004, 2006), y cuyos principios de funcionamiento podrían relacionarse con la importancia del lenguaje de los textiles (Cereceda 1990; Sinclaire 1999).

Junto a estos significantes más abstractos, coexisten otros de convenciones naturalistas, algunos de los cuales poseen una profundidad cronológica considerable (Muelle 1969; Berenguer 2004), observándose al mismo tiempo una tendencia a la esquematización de las representaciones figurativas y un fuerte sentido de abstracción en la construcción de otras imágenes.

La ruptura de la conquista hispana implicó la desaparición del discurso centralizado de los inkas, pero no evitó la emergencia de discursos atingentes a

\footnotetext{
A Marco Antonio Arenas, proyecto Fondecyt No 1130431. Santiago, Chile, email: marenas131@gmail.com

B María Carolina Odone, proyecto fondecyt N ${ }^{\circ} 1130431$. Pontificia Universidad Católica de Chile, Profesora planta adjunta, Instituto de Historia, Santiago, Chile, email: modoneco@uc.cl
} 
la nueva realidad colonial inscritos en aquellos espacios con importantes desarrollos locales del sistema rupestre. Si bien los aspectos singulares de los sistemas locales se mantienen, lo que llama la atención en el nuevo horizonte cultural impuesto por los europeos, es la similitud de las respuestas significantes, a pesar de las diferencias antes señaladas.

Por ejemplo, las escenas de monta o motivos ecuestres para nosotros constituyen, como sugirieron en su momento Gallardo et al. (1990), una composición significante de alta complejidad simbólica. Se presentan además, como un indicador de cambio de paradigma histórico reflejado en el sistema visual (Mege 2000; Mege \& Gallardo 2005). Proponiendo una cronología relativa, un segundo momento lo constituiría una suerte de eclosión de significantes vinculados a la expansión del cristianismo, manifestación que se caracteriza por un número acotado de significantes cristianos apropiados por el sistema, la mayoría de ellos de carácter figurativo (Martínez \& Arenas 2009). Junto a estos significantes, en muchos sitios se actualizan otros que se anclan en convenciones representacionales prehispánicas, como señal de una clara persistencia de la cultura propia (Martínez 2009; Arenas 2013; Arenas \& Odone 2015). Un problema particular lo constituyen los motivos abstractos, los cuales presentan continuidad desde el periodo prehispánico, pero en atención a la nueva realidad colonial aún no hemos prestado atención de buena forma a sus rupturas y continuidades.

También es posible observar algunas áreas con ciertos rasgos de unidad estilística y/o técnica. Por ejemplo, en las tierras altas del Cuzco y Espinar se observa el dominio casi exclusivo de las pinturas rupestres coloniales en color rojo (Hostnig 2004b), mientras que en el occidente de Oruro hay una presencia importante de pinturas rupestres en color negro (Arenas et al. 2015). Si observamos lo que está sucediendo en algunos valles y quebradas de Tarapacá, en el norte grande de Chile, la recurrencia mayor en el arte rupestre colonial parece darse con más fuerza en técnica de grabado (González, 2014). Lo mismo ocurre para el llamado norte chico de Chile (Arenas 2013).

Más allá de esta apretada síntesis, lo que interesa destacar aquí son las convenciones representacionales que se comparten dentro del sistema, algunas de las cuales ya se han mencionado para el caso de pinturas y grabados posibles de asociar al periodo inka. En lo estrictamente colonial, se apela a la construcción de los motivos figura- tivos a partir de la esquematización de las figuras, tanto si responden a diseños lineales o a la aplicación de campos de pintura de cuerpo lleno o areal (Gallardo 2005), para definir, por ejemplo, cuerpos y vestimentas. Cuando se compara la forma de construir la imagen figurativa, junto a otras de referente religioso cristiano y algunos motivos abstractos presentes en sitios como Chirapaca, al norte de La Paz (Taboada 1988, 1992), o a algunos de los sitios documentados por Hostnig (2004b) al sur del Cuzco, como Ichu Ancco Loma, Viscachani 2 y Morocaque (fig. 1), solo por citar algunos, con las convenciones representacionales usadas en el construcción de los llamados rezalipichis (fig. 2), en soportes de cuero y papel (Strecker

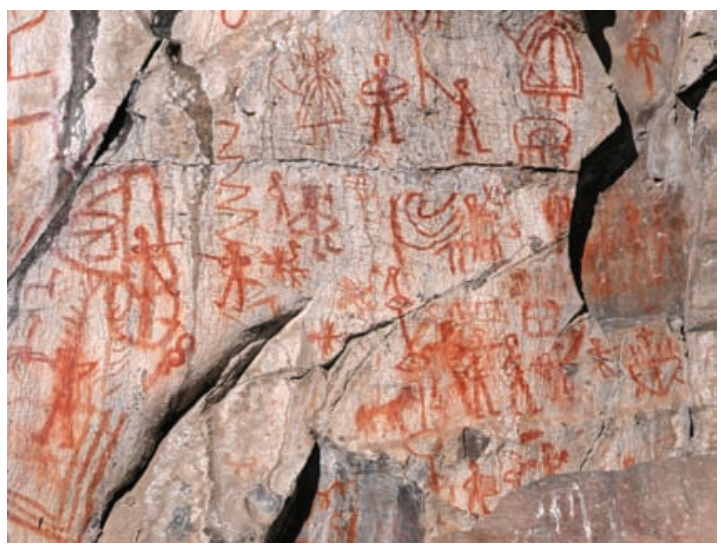

Figura 1. Morocaque, Subsitio 2. Vista parcial del panel 9. Provincia Espinar, Cuzco (fotografía gentileza de R. Hostnig). Figure 1. Morocaque, Subsite 2. Partial view of Panel 9. Espinar Province, Cuzco (photo courtesy of R. Hostnig).

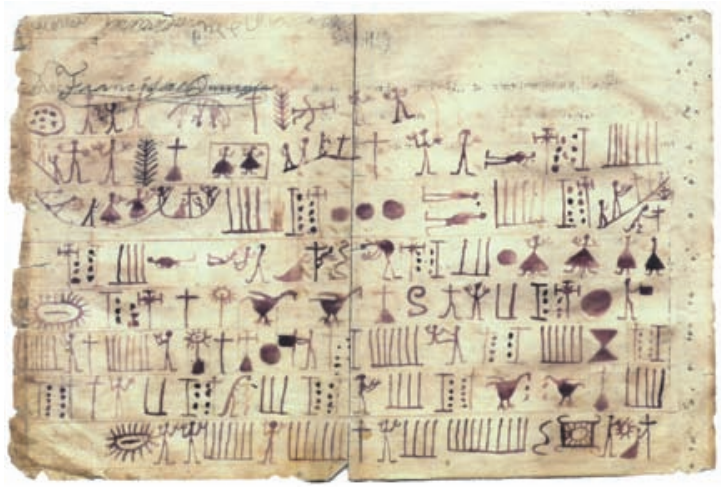

Figura 2. Rezalipichi en cuaderno rústico procedente de SampayaCopacabana (colección del INIAM-UMss, Cochabamba, en Garcés \& Sánchez 2015). Figure 2. Rezalipichi on rustic notebook from Sampaya-Copacabana (INIAM-UMSS collection, Cochabamba on Garcés \& Sánchez 2015). 
\& Taboada 1992; Garcés \& Sánchez 2014), creemos no estar en presencia de coincidencias estilísticas o técnicas, sino en formas de articular lenguajes visuales propios del mundo andino, en lo concerniente a una dimensión que hoy podríamos identificar con un lenguaje de carácter popular y que se expresa mayoritariamente en el sistema de arte rupestre colonial.

Estas convenciones de representación, tanto desde una perspectiva técnica como formal, circulan desde el soporte rupestre al soporte de muros de capillas e iglesias que, si bien algunas de ellas podemos identificar como de construcción colonial, otras nos sorprenden por su evidente actualidad.

\section{EJEMPLOS DE PINTURAS EN LAS PAREDES Y MUROS DE IGLESIAS COLONIALES}

En los pueblos de indios de espacios rurales de los Andes del sur (fig. 3), tempranamente, iglesias y capillas fueron lugares que se privilegiaron para que las gentes indígenas fuesen instruidas en las enseñanzas de la doctrina y de una vida virtuosa (A. de Lima, 565, Lib. II. Fol. 226, 1536, 67, en Lissón 1943); quedando claramente establecido que en ellas "no se han de hazer otras cosas ilícitas, ni den lugar a ello" (Ugarte 1951 Tomo I: 8.).

Por ende, las iglesias eran lugares vigilados y controlados a fin de que las prescripciones impuestas al uso de esos recintos no fuesen traspasadas (Vargas 1951,

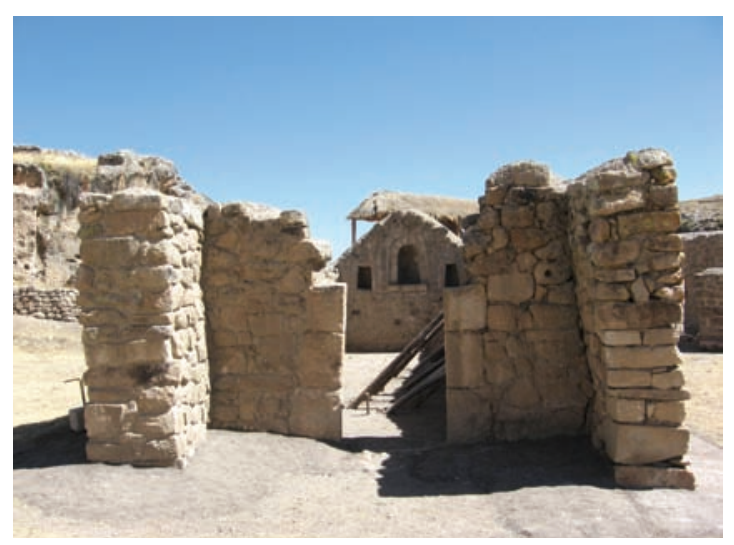

Figura 3. Capilla de Maukallaqta, sitio prehispánico tardío en territorio canas, alto Apurimac, intervenido por los españoles con la construcción de una capilla cristiana con arquitectura inka (fotografía de M. Arenas). Figure 3. Maukallaqta Chapel, late pre-Hispanic site on Canas territory, High Apurimac. The Spaniards intervened at the site by building an Inca-style christian chapel (photo by M. Arenas). tomo I: 14; Vargas 1952, tomo II: 155). En las iglesias o capillas que se encontraban situadas a más de una legua de las parroquias principales se detecta, para el siglo xvi, que su administración era débil y que, la mayoría de las veces, los doctrineros solo acudían "a celebrar las fiestas patronales y las propias de las cofradías" (Vargas 1951 Tomo I: 34).

En una de las disposiciones del Primer Concilio Provincial Limense (1551-1552) se informaba que en las "Yglesias de los pueblos de indios y en otros puntos los caminantes con poco acatamiento y reverencia se suelen entrar a dormir y en ellos hacen sus camas $y$ comen y beben y hacen otras cosas indebidas" (Vargas 1951 Tomo I: 58, énfasis nuestro). Este indicio permite pensar que efectivamente en las iglesias o capillas más alejadas ocurren hechos que no pueden ser controlados de forma inmediata, más allá de que se informe de ellos luego de la realización de visitas o recorridos pastorales.

Llama la atención el uso del término caminan$t e,{ }^{1}$ vocablo que asimilamos preliminarmente al de trajinantes caravaneros, encargados de efectuar viajes de tropas de llamos y/o mulas por diversos espacios, trasladando bienes y recursos, actividad que, pese a los controles hispanos, estaba en manos de las poblaciones indígenas (Sanhueza 1992; Medinacelli 2010). ¿Sería posible pensar que esos trajinantes/caminantes en sus viajes utilizarían las iglesias como lugares de descanso, tambo y/o paskana?

Esta pregunta plantea una segunda interrogante acerca de cómo habría sido esto posible si existían claras ordenanzas sobre mantener cerradas las iglesias y sólo abrirlas para las misas, la enseñanza de la doctrina o para la celebración de las fiestas religiosas católicas. En las mismas disposiciones del Primer Concilio Provincial Limense (1551-1552) se informa sobre una situación particular que está ocurriendo: "Yglesias y casas despobladas donde se solía hazer misa y enterrar algunos difuntos y de presente por haverse mudado el asiento de la doctrina a otra parte de los dichos pueblos [...], las dichas yglesias se an quedado despobladas" (Vargas 1951 Tomo I: 59). Haciéndose clara mención de que "se entran o encierran en ellas ganado o hacen otras indecencias” (Vargas 1951 Tomo I: 59, énfasis nuestro).

Vemos entonces que pese a las disposiciones eclesiásticas, las gentes andinas usan las iglesias o capillas de modos que no están permitidos por la iglesia oficial, traspasando las vigilancias que están impuestas. Siendo significativo que ello sea posible en iglesias o capillas 
que están situadas en sectores apartados, además de las que están bajo la categoría de "despobladas", las que fueron apropiadas por las gentes andinas, desde sus propias lógicas y usos: tambos/paskanas y corrales; siendo usadas y entendidas, desde prácticas culturales propias, allí se bebía, se comía, realizándose, a ojos hispanos, "indecencias". Singularmente, también transitaban hacia o estaban, en muchos casos, compuestas sobre/como wacas.

A su vez, y en este contexto de agencia indígena en los espacios sacros cristianos impuestos por la evangelización, se tienden a encontrar evidencias de imágenes que se "desplazaron" desde un soporte rupestre, a las paredes exteriores y/o interiores de algunas iglesias y capillas rurales. ${ }^{2}$ Lo que también es observado por el poder hispano cuando se informa de la práctica de las gentes andinas de mantener viva su memoria de adorar "aves y animales, los que además "[...] los pintan e labran en los [...] doseles de los altares, e los pintan en las paredes de las yglesias" (ANB E $1764 \mathrm{n}^{\circ}$ 131, f. 89v, año 1574, citado por Martínez 2012: 189, énfasis nuestro).

En las punas de la comunidad campesina de Chuquinga, del departamento de Apurimac (Perú) se encuentran las ruinas del asiento minero aurífero colonial de Huayllaripa. La construcción, en piedra y barro, de la iglesia del asiento habría comenzado a fines del siglo XVII, perteneciendo al partido o provincia de Aimaraes. El pueblo de Huayllaripa se situaba "en el centro de una depresión del terreno, rodeado por depósitos de terrenos de aluvión de bastante espesor, que los indios llaman las minas de Huayllaripa", las que eran trabajadas desde la antigüedad (Raimondi 1887: 745). En 1865 la producción intensiva de las mismas se encontraba abandonada, aunque los habitantes del poblado se ocupaban "casi exclusivamente en lavar las tierras auríferas para estraer el oro" (Raimondi 1887: 745). Técnicas muy particulares para el lavado de oro dieron origen al nombre del asiento minero, ya que "la palabra Huaillaripai quiere decir, lavar en paja" (Raimondi 1887: 746).

Es en esta tierra de oro donde el registro del arte rupestre está indicando la presencia de significantes abstractos y figurativos pintados en la fachada y pilares externos de la iglesia del asiento minero. Entre estos últimos se observan motivos fitomorfos, además de motivos antropomorfos y camélidos. No sabemos si las pinturas fueron ejecutadas durante el ciclo minero intensivo o bien fueron hechas después de que la pro- ducción de sus lavaderos de oro decayó. Lo singular de estas representaciones es que participan de las mismas convenciones representacionales del arte rupestre. Pintura de color rojo, trazo lineal en este caso grueso, pintura areal plana y disposición conjunta de significantes abstractos y figurativos. Por convención representacional y forma significante pensamos que estos motivos se despliegan desde una tradición de arte rupestre a los muros exteriores de la iglesia de Huayllaripa (figs. 4 y 5).

En la iglesia de Chuquinga, cabecera de doctrina de la iglesia de Huayllaripa, se presentan evidencias también interesantes. Un aspecto significativo es que el paraje de Chuquinga ancla en la memoria colonial del siglo XVI, ya que dicha área fue el escenario del enfrentamiento entre las fuerzas de Francisco Hernández Girón y del mariscal Alonso de Alvarado, en 1554, en el contexto de las guerras civiles en el Perú. Relata Guamán Poma de Ayala que Girón llegó al "pueblo de Chuquinca y comensó a entablarse en una fortalesa de los yndios antiguos de Auca Runa que tenía una puerta prencipal y detrás su puerta falsa" (Guaman Poma 1980 [1615-1616], Tomo II: 399), fortaleza que ya estaba levantada en tiempos de Capac Yupanqui (Vásquez de Espinosa 1628-1629: 532). A su vez, y para 1591, se tienen referencias de que Pedro Guanbotoma era el curaca que representaba "a la parcialidad de los Yano ayllos que abarcaba a los pueblos de Chuquinga, Sañayca, Capaya y Toraya", siendo "Damian Tanislla principal" de Chuquinga (Maldonado \& Estacio 2012: 49, 105).

En 1676 el obispo del Cuzco, Manuel de Mollinedo y Ángulo, como parte de su visita pastoral, visitó la

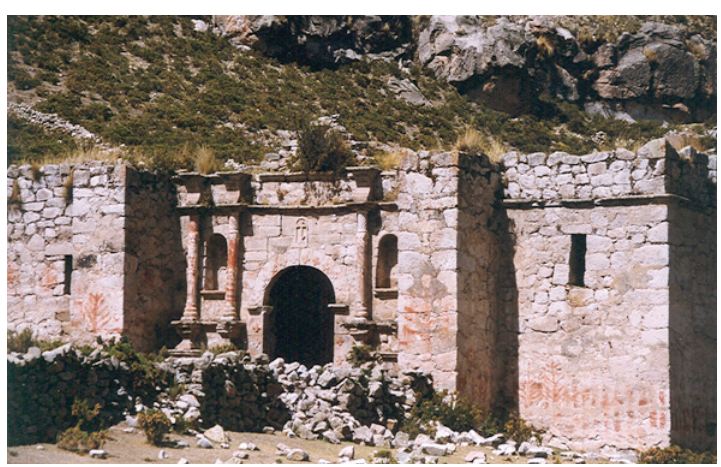

Figura 4. Vista de la iglesia de Huayllaripa en el asiento homónimo. Provincia Aymaraes, Apurimac, Perú (fotografía gentileza de R. Hostnig). Figure 4. View of the Church of Huayllaripa in the settlement of the same name. Aymaraes Province, Apurimac, Peru (photo courtesy of R. Hostnig). 


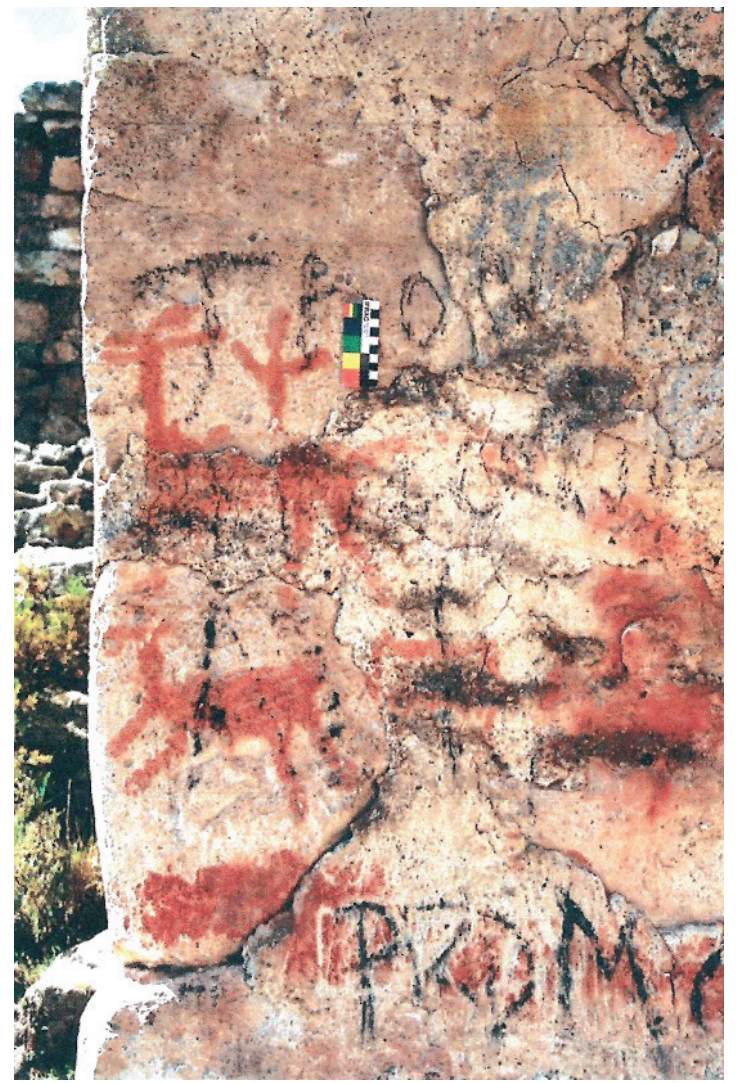

Figura 5. Detalle de representaciones de camélidos y otros motivos abstractos en un pilar exterior de la iglesia de Huayllaripa. Provincia Aymaraes, Apurimac, Perú (fotografía gentileza de R. Hostnig). Figure 5. Detail of representations of camelids and other abstract motifs on an exterior pillar of the church of Huayllaripa. Aymaraes Province, Apurimac, Peru (photo courtesy of R. Hostnig).

doctrina de Chuquinga, conformada por tres pueblos, Chuquinga, Payraca y Mutca, contando la doctrina con mil feligreses, siendo imposible reconocer el total de población indígena comprometida en esa cifra. También se señala que las iglesias de esos pueblos tenían cuatro cofradías, siendo imposible establecer cuántas de ellas correspondían a cada una de las iglesias. Durante la visita se mandó que el cura de la iglesia de Chuquinga, Joseph de Mesa, "hiciese poner un estrivo por la parte defuera a la iglesia de Chuquinga; y despachase a esta ciudad dos aras para que yo las consagrase. Hiço imbentarios de los bienes, alajas y ornamentos" (Visita del año 1676 f. 5v en Guibovich \& Wuffarden 2008: 116). Para el año 1687 se señala que el cura de la iglesia era Diego del Pesso de Vera, y que en la iglesia existían los siguientes ornamentos: "un bernegal de plata de un marco, unos

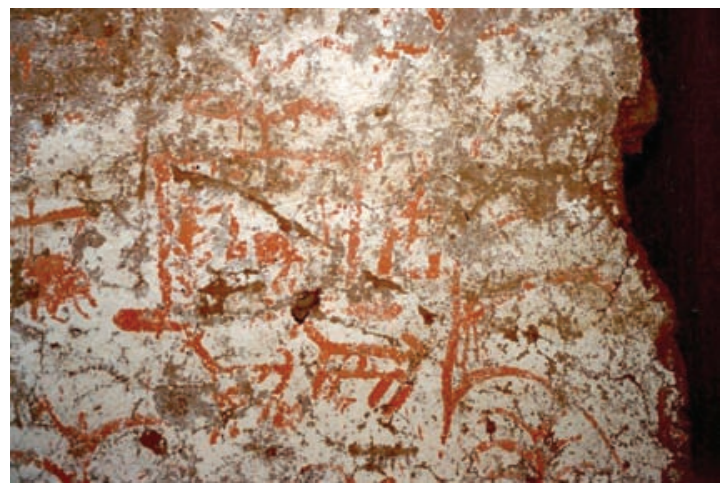

Figura 6. Motivos zoomorfos y otros no identificados de tradición rupestre en un muro interior de la iglesia de Chuquinga. Provincia Aymaraes, Apurimac, Perú (fotografía gentileza de R. Hostnig). Figure 6. Zoomorphic and unidentified traditional rock art motifs in an interior wall of the church of Chuquinga. Aymaraes Province, Apurimac, Peru (photo courtesy of R. Hostnig).

manteles de ruán florete, un chuze de colores" (Resumen de la visita del año 1687 f. 5 v en Guibovich \& Wuffarden 2008: 194, énfasis nuestro). Pareciera ser que el chuze de colores hace referencia al tejido de un tapete de lana y salvo este ornamento, el resto de los objetos de la iglesia son de una clara factura hispano-colonial.

Sin embargo, el registro de motivos que descansan en convenciones de representación del sistema rupestre permite detectar que no toda la iglesia está llena o forma parte de la cosmovisión hispano-cristiana, puesto que en lo que parece corresponder a los restos laterales de un altar, se conserva parte de la decoración que consistía en un recubrimiento blanco, que actúa como fondo, decorado con motivos fitomorfos y camélidos, estos últimos de acuerdo con las convenciones de representación del sistema rupestre (fig. 6).

En el departamento del Cuzco, sobre los 4.000 msnm, se sitúa el poblado de Yauri, su iglesia dataría del siglo XVII. No conocemos la fecha de su fundación, sabemos sí que es una iglesia del periodo colonial y que tanto su nave central como su torre campanario descansan sobre los restos de una antigua w'aka. A su vez, las bases y muros de la iglesia son de cal y piedra, y su piso es de madera. La iglesia fue construida y reconstruida en tiempos coloniales (siglos XVII y xVIII) y republicanos (1847), levantándose una edificación religiosa donde se combinan los estilos barroco andino y mestizo y el neoclásico. ${ }^{3}$

Para comienzos del siglo xvir contaba con 801 tributarios (Vásquez de Espinosa 1628-1629: 659). En 
1675 tenía una "feligresía de más de 2.200 personas. Tiene 7 cofradías: la una, del Niño Jesús [...]; otra, de la Limpia Concepción de Nuestra Señora [...]; otra, de la Purificación de Nuestra Señora [...]; otra, del Santísimo Sacramento [...]; otra, de San Joseph [...]; otra, de Santa Ana [...]; Tiene una cofradía de las Ánimas del Purgatorio [...]" (Visita del año 1675 f. 3v en Guibovich \& Wuffarden 2008: 90-91). Lo que permite plantear que, al menos, a fines del siglo xvis, era una iglesia muy activa; y que sus cofradías sostenían su culto, básicamente, con ovejas, ovejas de la tierra (camélidos), y ganado vacuno. Reconociéndose además que era "una iglesia mui hermosa de fábrica y mui rica de ornamento y halajas" (Visita del año 1675 f. 4r en Guibovich \& Wuffarden 2008: 91).

Hacia 1687 se reconoce que en la iglesia de "Iauri se a hecho una crus de plata dorada y esmaltada muy rica, y se está haciendo un retablo para el altar mayor que corresponda a la iglesia, que es muy hermosa. Esta toda pintada y dorada y alfombrada, y del que oy tiene se an de hacer dos retablos para los dos colaterales. Toda ella se a reparado y enlucido por defuera y se está haciendo el choro" (Resumen de lo que se a obrado [ ...] f. 6v en Guibovich \& Wuffarden 2008: 128).

Es decir, una iglesia llena de usos y apropiaciones hispano-cristianas que a lo largo del siglo Xvil se fue ornamentando y alhajando desde modos estéticos europeos, proceso que fue conducido y vigilado por clérigos locales y el obispo del Cuzco. Sin embargo, el registro del arte rupestre nuevamente está alumbrando sobre otros procesos que están ocurriendo en la iglesia ya que en los muros exteriores de la torre campanario se observa la pintura de motivos fitomorfos y cruces calvarios. Dichos significantes comparten las convenciones de representación que, para motivos similares, se emplean en el sistema de arte rupestre colonial (fig. 7).

En efecto, en el territorio del cual Yauri es la capital provincial se encuentra una importante concentración de sitios de arte rupestre colonial con un extraordinario predominio de pinturas rupestres en color rojo, y con una importante concentración de motivos religiosos cristianos, especialmente cruces latinas y cruces calvarios, entre otros (Hostnig 2004).

Una de las preguntas que surge es cuándo la torre campanario fue pintada con significantes de tradición rupestre (sensu Hostnig 2003). Pensamos que necesariamente tendría que haber ocurrido después de las últimas décadas del siglo XVII, porque en el año 1687 se mandó

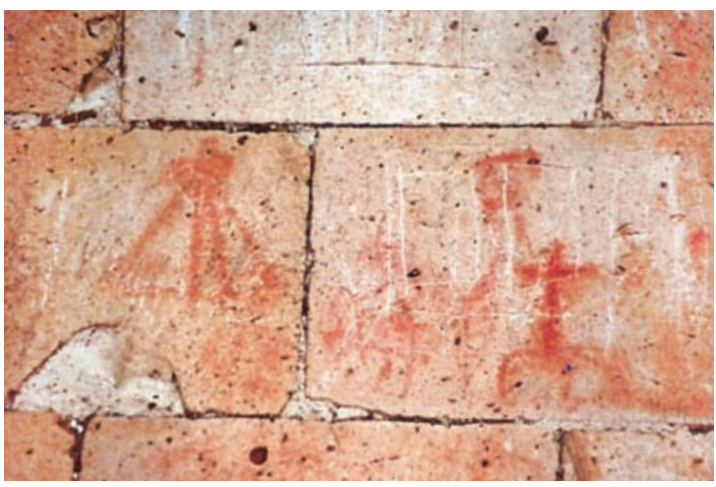

Figura 7. Pinturas de tradición rupestre colonial en los muros exteriores de la iglesia de Yauri. Provincia Espinar, Cuzco, Perú (fotografía gentileza de R. Hostnig). Figure 7. Paintings from the Colonial era rock art tradition on the exterior walls of the church of Yauri. Espinar Province, Cuzco, Peru (photo courtesy of R. Hostnig).

"que se acabe la torre; que las gradillas del presbyterio se deshagan" (Resumen de la visita año 1687 f. $5 \mathrm{r}$ en Guibovich \& Wuffarden 2008: 209). Detallándose que se le han incorporado una serie de ornamentos como "una bara de cruz alta de plata, un trencillo de oro de la llave del sagrario, un almisal de tafetán de carmesí, tres síngulos de seda, 7 amitos de Bretaña, unos caxones de cedro, un sepulchro, seis hacheros, ocho liencos, una barreta" (Resumen de la visita año $1687 \mathrm{f}$. $5 \mathrm{r}$ en en Guibovich \& Wuffarden 2008: 209), todos adornos de una clara pertenencia a la cosmovisión cristiana-católica.

Claramente la pintura de la torre campanario nos remite a un sentido de apropiación simbólica andinocolonial, pero ¿qué podrían estar significando o diciendo gentes indígenas de Yauri con las pinturas de la torre campanario emplazadas de forma absolutamente visible?

Si estas pinturas no se realizaron en el siglo XVII, ¿habría que explorar, en Yauri, acontecimientos en el siglo xviIr? En las últimas décadas del siglo xVIII, Yauri, situado en la provincia de Canas y Canchis, era un curato que contaba con dos santuarios, el de la Virgen de Huancani y de la Candelaria (Valcárcel 1947: 49). En 1780 tenía como cacique a Francisco Guambatupa (O'Phelan 1979: 93). ${ }^{4}$ El 10 de noviembre de 1780 José Gabriel Condorcanqui, conocido como José Gabriel Túpac Amaru, escribía que se notificase a diferentes pueblos, entre ellos al de Yauri, que todos los indios acudiesen a Tungasuca para integrar las fuerzas tupacamaristas, y en caso contrario serían castigados, mandando además que sus disposiciones fuesen pegadas en las puertas de las iglesias de los poblados (Relación 
sobre la sublevación de Túpac Amaru [varios] noviembre 1780 en Comité Arquidiocesano del Bicentenario Túpac Amaru 1983: 204-205).

El movimiento de rebelión iniciado por Túpac Amaru, cacique de Surimana, Pampamarca y Tungasuca, en la provincia de Tinta o de los Canas y Canchis, generó una seria insurrección en el sur-andino del virreinato del Perú, incluyéndose también la región altiplánica o el Alto Perú. ${ }^{5}$ El movimiento o rebelión de Túpac Amaru se inició el 10 de noviembre de 1780 en Tungasuca, con el ahorcamiento del corregidor Antonio de Arriaga, reuniendo Túpac Amaru a su gente, en la plaza del poblado, haciéndola marchar "al son de tambores y pututus" (Valcárcel 1947: 74). Túpac Amaru, contó con el apoyo del cacique de Yauri, Francisco Guambatupa (O'Phelan 1979: 93).

¿Sería posible pensar que en este contexto revolucionario la iglesia de Yauri fuera marcada con todos los signos de la indianidad insurreccional?, ¿ fue este estallido un momento de semiosis, de registro y comunicación de los acontecimientos que estaban sucediendo?, ¿ ¿se podría pensar a los motivos fitomorfos y cruces calvario de la torre campanario como parte de esa semiosis?

Los rebeldes utilizaban "cruces tupacamaristas en los sombreros, 'como insignias de buenos cristianos"' (Valcárcel 1947: 141), ¿esa insignia se traspasó a otros soportes como la torre campanario? No podemos afirmarlo, pero sí nos parece significativo que la cruz pintada de rojo era el distintivo de la bandera del movimiento que pasó por Yauri: "Some of his followers waved a white flag with a red cross" (Walker 2014: 4).

Por otra parte y respecto de la cruz roja, Walker, indagando tanto en la declaración de Micaela Bastidas Puchucahua, mujer de Túpac Amaru, como en la de otros tupacamaristas que fueron tomados prisioneros señala que "the closest thing they had to a uniform were hay or palm crosses such a those distributed on Palm Sunday that many of them wore in their hats. One prisoner admitted that he wore both the cross and a red embroidery, 'the insignias of the rebels'. In December 1780, Micaela Bastidas ordered that they display the crosses in their hat 'as a sign that they are good and true Christians"' (Walker 2014: 43).

Es interesante reconocer que la cruz de color rojo es un distintivo significativo, observándose la diferencia entre las cruces de paja o de palma que los rebeldes prendían en sus sombreros. No deja de ser interesante el detalle de las cruces de palma como las que se distri- buían el domingo de Pascua, ¿podrían corresponder los motivos fitomorfos a hojas de palma? ¿Es aquella una representación andina de la cruz cristiana? Claramente la cruz es una insignia de los rebeldes, pero ¿qué se entiende por el bordado rojo?, ¿la cruz estaba embarrilada en lanas de color rojo o bien bordada en los sombreros?

La insurrección comenzó el 4 de noviembre con la captura del corregidor Antonio de Arriaga, y su ejecución el 10 de noviembre 1780. En abril de 1781 Túpac Amaru fue capturado y el 18 de mayo fue ejecutado en la plaza del Cuzco. El 10 de noviembre de 1780 José Gabriel Condorcanqui escribía un bando para que todos los pueblos se plegasen al movimiento, bando dirigido a Yauri, donde su cacique, Francisco Guambatupa, lo apoyó. Desde este marco de referencia, sugerimos que las pinturas rupestres asociadas a representaciones bélicas, como las del sitio de Morocaque y otros, podrían estar asociadas al contexto de la rebelión. Dichas pinturas también se contextualizan en sitios con una considerable carga religiosa. Y en ese contexto de rebelión, la participación de gentes de Yauri en los distintos combates que sobrevinieron, debieron estar marcados por diferentes rituales. Por una parte, utilización de hojas de coca y chicha para preparar ritualmente a las gentes andinas para el combate. Celebraciones de rituales de brindis entre Túpac Amaru y el cacique Francisco Guambatupa, ya que efectivamente Túpac Amaru reprodujo, a lo largo del movimiento, una serie de rituales de brindis con autoridades étnicas locales a fin de establecer lazos de cooperación y reciprocidad: "sacó exprofesamente un frasco de vino y un vaso de cristal quebrado y en él se hizo beber a todos y a poco tiempo mandó sacar otro vaso entero en el que bebieron. Que estando en la mesa les dijo el dicho Túpac Amaru que fueran parciales suyos" (CDRTA Tomo I: 379 en O'Phelan 1995: 150). Sugiere O'Phelan que los vasos quebrados estarían asociados a la costumbre de las familias de guardar "vasos extraídos de entierros antiguos" (1995: 150).

Además, y en el contexto de la rebelión, Yauri ocupará un lugar, simbólicamente importante. De acuerdo con la documentación histórica referida a la distribución de los cuerpos o parte de ellos, de los nueve reos principales de la rebelión una vez asesinados en la plaza de Cuzco el 18 de mayo de 1781, se señala que algunos de ellos fueron ahorcados, con el castigo previo de corte de sus lenguas; las mujeres fueron ajusticiadas con "garrote sobre un tabladillo, que estaba dispuesto con un torno de fierro" (Valcárcel 1947: 178). Partes de 
sus cuerpos fueron llevados a diferentes poblados: Diego Bendejo o Verdejo fue ahorcado, "su cabeza llevada a Chuquibamba, un brazo a Coporaque, el otro a Yauri" (O’Phelan 1979: 116).

Volviendo al proceso de semiosis señalado más arriba, las cruces de adorno portadas en los sombreros como distintivos de buenos cristianos remiten a la asimilación del cristianismo, condición importante de destacar por los dirigentes del movimiento insurreccional. Se ha señalado en otros lugares que, en lo que hemos llamado un proceso de apropiación selectiva de significantes cristianos traspasados al sistema de arte rupestre (Arenas \& Odone 2015), las cruces latinas y sus variantes constituyen el significante más representado (ver el caso del sitio Toro Muerto en el norte chico de Chile en Arenas 2013). También es importante destacar aquí, a propósito de las rebeliones indígenas del siglo xviII, que existe una clara construcción de discursos bélicos asociados al sistema rupestre. Discursos constitutivos de una posible semiosis como consecuencia de dichos acontecimientos.

\section{LOS UNIVERSOS DE LO PROPIO}

Las expresiones visuales de las iglesias de Huayllaripa, Chuquinga y Yauri se enmarcan en prácticas que, desde lenguajes propios, las gentes andinas continuaron desarrollando, pese a los profundos cambios y transformaciones que vivieron luego de la conquista hispana del siglo XVI, siendo insoslayable reconocer que esas expresiones visuales comportan "creencias, propósitos y sentimientos profundos" (Gallardo et al. 1990: 29).

Otro despliegue visual significativo lo encontramos en la iglesia de Tolapampa, situada en el actual cantón de Tolapampa, al sudeste de Potosí. La historia del poblado de Tolapampa ancla en una historia antigua asociada con la importante confederación multiétnica de los Quillacas y sus unidades domésticas, las que a partir de mediados del siglo xvi fueron reducidas en distintos pueblos. Las unidades domésticas de Civaroyos o Siwaruyos junto a las de Arakapi o Aracapis fueron reducidas en los pueblos de Tomahave, Tolapampa y Coroma (Saignes 1986: 16). Estos tres pueblos, a partir de las reducciones del virrey Francisco de Toledo, fueron elevados a la categoría de curatos o parroquias principales que comprendían otros anexos parroquiales. Ahora bien, las unidades domésticas de los Civaroyos y
Arakapi estaban también asentadas en un pueblo ubicado en las cercanías de Potosí, hacia el sudeste, el pueblo de Puna. A partir de los reordenamientos toledanos los que ocupaban el repartimiento de Puna fueron reducidos en los pueblos de Talavera de Puna y de Todos Santos de Quiocalla (Bubba 1997: 379-381). Los efectos de las reducciones que desajustaron los antiguos territorios indígenas se observan cuando en 1663, Juan Zárate, gobernador y cacique principal del pueblo de Puna, de la parcialidad de los Cirovayos, presenta una petición junto a los demás indios de la parcialidad de los Arakapi: "incluyendo dentro de estos grupos a don Bernabé Hallasa, segunda persona del pueblo de Coroma y don Juan Ayssa, segunda persona del pueblo de Tolapampa" (EC 1663, n 30, f. 60. ANB citado en Bubba 1997: 380). ${ }^{6}$

Pareciera ser que entre 1596 y 1604, durante el gobierno del virrey Luis de Velasco, Tolapampa se convirtió "en un pueblo de reducción de ambas parcialidades: Siwaruyo y Arakapi” (Bubba 1997: 381). Respecto de la iglesia de Nuestra Señora del Carmen de la reducción de Tolapampa no contamos con antecedentes que permitan reconocer si se comenzó a construir a fines del siglo XVI o bien en el siglo xvir. Lo que sí podemos identificar es que se trata de una construcción de barro, observándose que en lo que corresponde al espacio del retablo, donde se integran a la arquitectura de barro el altar, acompañado de columnas, hornacinas y nichos. La parte superior de las hornacinas fue decorada con un motivo discreto de aves sobre un árbol o planta, emulando tímidamente las alegorías al paraíso de las iglesias de Curahuara de Carangas o Copacabana de Andamarca. Lo que nos llama la atención es la representación de un zoomorfo en pintura lineal roja, al lado derecho del altar, entre este y un nicho. Inmediatamente al lado derecho de este nicho se observa un motivo fitomorfo, como una suerte de convención utilizada para representar la planta del maíz o bien una palma en el sistema rupestre (fig. 8).

Hacia fines de 1780 y comienzos de 1781 Tolapampa vivió la conmoción del movimiento revolucionario. El movimiento que se había iniciado en las provincias de Canas y Canchis, también se extendió al Alto Perú, a Oruro, Chayanta, Paria, Larecaja, La Paz, Chucuito y alrededores, dirigido por Tomás Catari y Julián Apasa Nina Túpac Catari. Tomás Catari originario del pueblo de Macha en la provincia de Chayanta, parte de lo que fuera la confederación de Quillacas, fue detenido en diciembre de 1780, siendo asesinado en enero de 1781 en las cercanías de la ciudad de La Plata o Chuquisaca. 


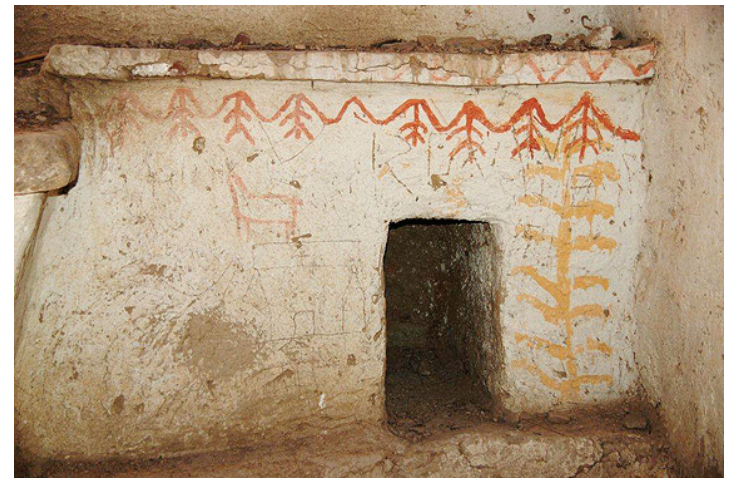

Figura 8. Vista de detalle del altar de la capilla de Tolapampa, donde destacan un motivo zoomorfo y otro fitomorfo. Cantón Tolapampa, Potosí, Bolivia (fotografía gentileza de R. Hostnig). Figure 8. Deatil of the altar in the chapel of Tolapampa, highlighting a zoomorphic and a phytomorphic motif. Tolapampa Canton, Potosi, Bolivia (photo courtesy of R. Hostnig).

Diego Dámaso Catari, hermano de Tomás Catari, mantenía contactos y relaciones con Túpac Amaru. En abril de 1781 se tomó la declaración al reo Diego Dámaso Catari, acusado de ser el principal motor de la sublevación en la provincia de Chayanta (Hidalgo 2004 [1983]). Declara que "Dijo: que dicho Miguel Michala, Ventura Cruz, indio de Coroma, y cinco que vinieron de Tolapampa, cuyos nombres ignora, le aseguraron que, unidos los indios con los criollos, habían muerto a todos los chapetones en Oruro, donde esperaban a Tupac-Amaru, que estaba cerca con 8.000 criollos y 6.000 indios, que venían matando a todos los españoles europeos" (Relación histórica... el año de 1780: 223, énfasis nuestro).

Este marco de referencia nos permite plantear que el pueblo de Tolapampa estuvo inserto en este contexto insurreccional aymara, pero perturbado además por enfrentamientos entre españoles y mestizos que entraron a robar al pueblo (Szemiñski 1974: 38).

En las expresiones visuales de las iglesias de Huayllaripa, Chuquinga, Yauri y Tolapampa observamos que una serie de significantes, la mayoría en pintura roja, funcionan algunos, de manera discreta, en muros interiores de iglesias y/o posas. En otros casos, como en Huayllaripa y Yauri, se disponen en lugares absolutamente visibles como la torre campanario. Pero en todas ellas se distingue la tendencia a la disposición y un parecido extraordinario a las convenciones rupestres de representación, fenómeno que también se distingue en otras iglesias o capillas rurales. Están ahí como ejemplo los motivos de "iglesias" y cruces, antropomorfos y camélidos

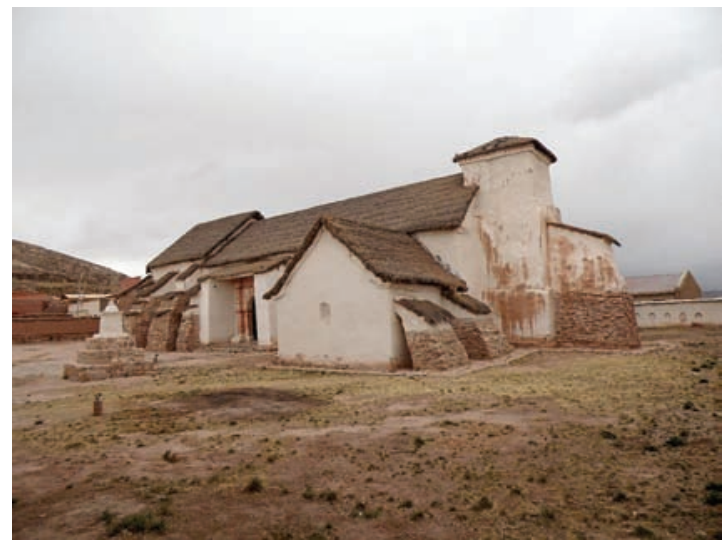

Figura 9. Iglesia de Curahuara de Carangas, Oruro, Bolivia (fotografía de M. Arenas). Figure 9. Church of Curahuara de Carangas, Oruro, Bolivia (photo by M. Arenas).

observados en la iglesia de Lagunas y Markachavi, en el altiplano de Oruro, entre otras.

Las evidencias que hemos presentado sobre las expresiones visuales de las iglesias de Huayllaripa, Chuquinga, Yauri, Tolapampa, Lagunas y Markachavi no tienen una investigación que se corresponda con los significativos estudios que en el altiplano de los Andes del sur se han realizado en torno a iglesias mayores y capillas menores que cuentan con bellas expresiones de pinturas murales, tradición pictórica iniciada en el siglo xvi y que continúa hasta el día de hoy. Emblemáticas han sido las investigaciones de las iglesias del altiplano de La Paz, como las de Carabuco, Tiwanaku y Callapa, las que contienen amplios conjuntos de pintura mural (Mesa \& Gisbert 1977; Arze 2013). Para el caso del altiplano de Oruro, destacan las pinturas murales de San Santiago de Curahuara (fig. 9), consideradas como las más antiguas de la región (Mesa \& Gisbert 1962; Gisbert 1998; Medinacelli \& Uchanier 2012; Arze 2013; Medinacelli 2013; Antequera 2013). Además de las investigaciones efectuadas en las iglesias de los Altos de Arica o Doctrina de Codpa, las que contienen imágenes asociadas a programas iconográficos existentes en esas otras iglesias de los Andes del Sur (Chacama et al. 1988-1989; Chacama 2009; Corti et al. 2010a y b; Corti et al. 2013).

En esas pinturas murales son significativas las representaciones de infiernos, paraísos y juicios finales; junto a escenas de la pasión y muerte de Cristo, la Virgen María, ángeles, santos, escenas bíblicas, personajes del Antiguo Testamento; además de temáticas asociadas 
con la mitología clásica, entre otras; motivos como flores, vegetación en general, aves, guirnaldas, y seres fantásticos, por nombrar algunos (Gisbert 1980; Macera 1981; Flores et al. 1991). Pinturas murales que también han sido asociadas con programas iconográficos de orden moral, doctrinal, devocional y penitencial, directamente vinculados con la catequesis y evangelización de poblaciones indígenas, cuyos significantes se fueron constituyendo en modelos aplicados en murales de diversas iglesias y capillas de los Andes del sur. Serían entonces programas iconográficos considerablemente formalizados que respondían a la necesidad de transmitir e imponer ideas respecto del adecuado orden moral (Flores et al. 1991; Castro et al. 2009; Gisbert \& Mesa 2010; Corti et al. 2010a y b; Guzmán 2013).

Los ejemplos que se presentan en las iglesias de Huayllaripa, Chuquinga, Yauri, Tolapampa, Lagunas y Markachavi, nos sitúan en otros dominios de la experiencia visual andina, aquella que no está asociada con programas iconográficos fuertemente formalizados.

Sin embargo, las gentes andinas también fueron capaces de transitar entre dos mundos, el propio y el de los dominadores. Un ejemplo de este tránsito lo reconocemos en la iglesia de Santiago de Curahuara de Carangas, bautizada como "la capilla sixtina de los Andes" y que presenta un despliegue visual policromo de su interior que, aunque obedeciendo a la ortodoxia de la iglesia católica, se observa la sutil percolación de la ideología indígena con la instalación de una serie de significantes, mínimos frente al despliegue visual europeo dominante, pero con una importante carga de sentido. En efecto, el estudio iconográfico del padre Gabriel Antequera (2013) identifica no solo la mano indígena en el estilo de algunas de las representaciones, sino además la instalación de algunos significantes del mundo simbólico andino. En la pared interior frente a la entrada principal se observa una notable representación del juicio final. En el centro y parte superior de la obra se observa la imagen de Cristo Rey vestido de rojo, sentado sobre un arcoíris y posando los pies sobre la tierra. Flanqueando la figura de Cristo por ambos lados, se instalaron una imagen del sol y una imagen de la luna, acompañados de los símbolos del martirio (fig. 10). El padre Antequera también reconoce la presencia del sol y la luna integrada con la imagen simbólica del Espíritu Santo, ubicada en el techo del baptisterio (Antequera 2013: 84-85). Asimismo en el baptisterio se puede observar la representación de San Francisco Xavier.

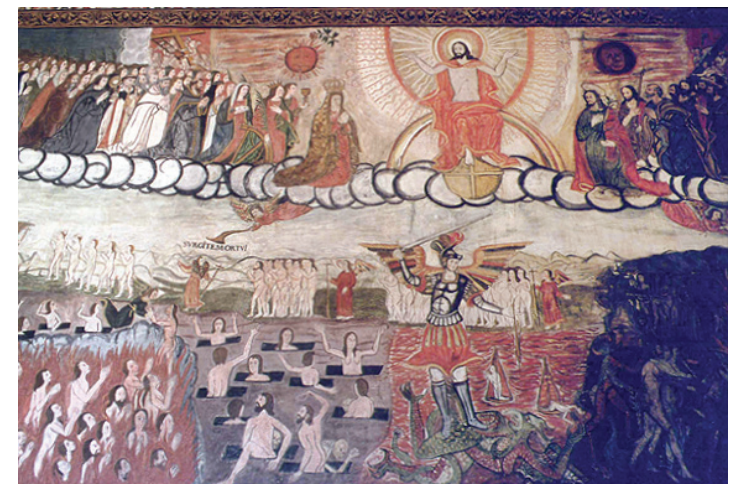

Figura 10. Representación del Juicio Final en la pared frente a la entrada principal de la iglesia de Curahuara de Carangas, Oruro, Bolivia. Obsérvese en la parte central superior de la representación la imagen de Cristo Rey flanqueado por una imagen del sol y otra de la luna (fotografía de M. Arenas). Figure 10. Representation of the Final Judgment on the wall facing the main entrance of the church of Curahuara de Carangas, Oruro, Bolivia. Note the image of Christ flanked by a sun and moon in the top center of the painting (photo by M. Arenas).

Lo singular es que el santo se encuentra bautizando a un grupo de indígenas vestidos con túnicas a modo de unkus y portando penachos de plumas. En la misma representación, un grupo de "indios conversos" con las singulares camisetas de autoridades andinas, pero sin penachos en la cabeza (fig. 11). El diseño del damero del inka ocupa un lugar central en la representación, señalando la importancia de estas autoridades en la localidad. ${ }^{7}$ Un tercer significante andino es la presencia del cóndor en la composición del Arca de Noé. En dicho cuadro mural se observa un par de cóndores dirigiéndose al arca junto a otros animales (fig. 12). Un detalle que comenta el padre Antequera y que nosotros compartimos, es que estas imágenes de cóndores corresponden a los únicos componentes de la fauna local presentes en dicha composición. Al respecto debemos señalar que en el arte rupestre prehispánico y colonial del territorio de Carangas cercano a Curahuara se observa la importancia del cóndor en la representación (figs. 13 y 14).

\section{COMENTARIOS FINALES}

En relación con la discusión en torno a universos representacionales andinos en instalaciones religiosas en sectores de los Andes del sur, es posible establecer que efectivamente en los alrededores o bordes rurales estaría funcionando un espacio representacional no europeo, un 


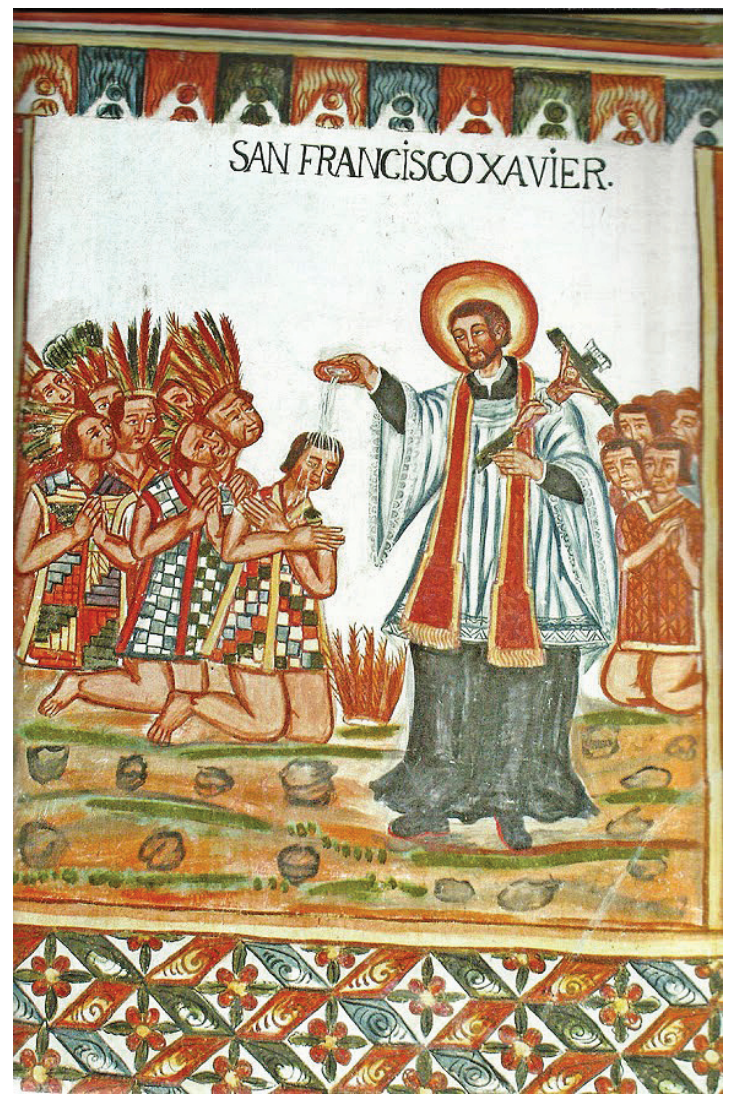

Figura 11. Representación de San Francisco Xavier bautizando a autoridades indígenas. Baptisterio de la iglesia de Curahuara de Carangas, Oruro, Bolivia. Obsérvese el detalle del unku "damero del inka" (fotografía de M. Arenas). Figure 11. Representation of Saint Francis Xavier baptizing indigenous authorities in the baptistery of the church of Curahuara de Carangas, Oruro, Bolivia. Note the detail of the "Inca checkerboard" unku tunic (photo by M. Arenas).

espacio simbólico o sacralizado otro, autónomo, incluso alternativo de programas iconográficos evangelizadores oficiales. Consideramos que allí no solo se están filtrando otras nociones religiosas, sino que ideas cristianas indígenas están representándose, incluso recreándose nuevos repertorios visuales producidos del necesario diálogo entre lo católico y lo andino religioso.

A su vez, reconocemos que convenciones representacionales rupestres andinas están migrando a los templos cristianos. Allí se observan motivos, cuya disposición, composición, técnica de ejecución, diseño, materiales o pigmentos, ${ }^{8}$ son más bien propios del arte rupestre. En las fachadas de las iglesias se observa la disposición de significantes abstractos y figurativos (fitomorfos, antropomorfos y camélidos) pintados de color rojo,

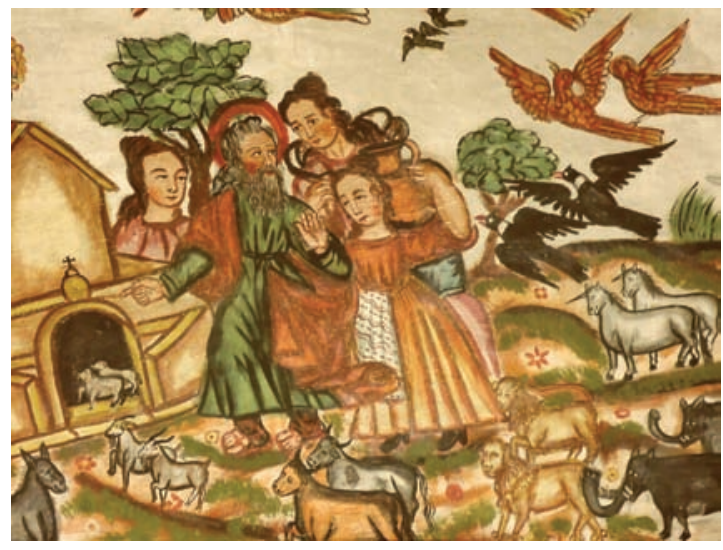

Figura 12. Representación de una pareja de cóndores en la escena del Arca de Noé, baptisterio de la iglesia de Curahuara de Carangas, Oruro, Bolivia (fotografía de M. Arenas). Figure 12. Representation of a pair of condors in the Noah's Ark scene in the baptistery of the church of Curahuara de Carangas, Oruro, Bolivia (photo by M. Arenas).

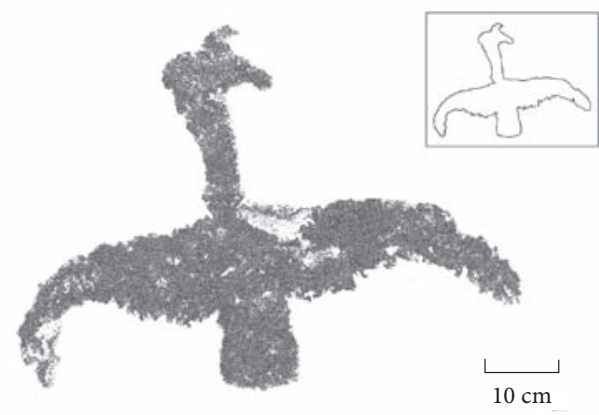

Figura 13. Representación del cóndor en el sitio de Q'urini 3, comunidad de Villa Irpoco, Oruro, Bolivia (fotografía de M. Arenas. Procesada con DStrech, canal ybk). Figure 13. Representation of a condor at Q'urini 3 site, Villa Irpoco community, Oruro, Bolivia (photo by M. Arenas. Processed with DStrech, ybk enhancement).
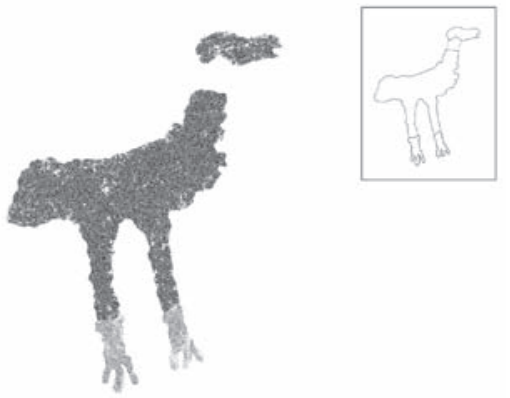

Figura 14. Representación del cóndor en el sitio de Qilqata, Comunidad de Yarake, Oruro, Bolivia (fotografía de M. Arenas. Procesada con DStrech, canal lab). Figure 14. Representation of a condor at Qilqata site, Yarake community, Oruro, Bolivia (photo by $M$. Arenas. Processed with DStrech, canal lab). 
distinguiéndose trazos areales planos y lineales finos y gruesos. Estos motivos se encuentran en las fachadas de las iglesias coloniales, como las de Huayllaripa y Yauri. También nos encontramos con motivos figurativos y las cruces calvarios, que igualmente se representan en los muros interiores de las iglesias, como en Chuquinga, Tolapampa y Markachavi: su representación guarda afinidad con las representaciones del sistema del arte rupestre colonial.

Reconocemos entonces que hacedores/productores/ ejecutantes, de modo performativo, dejan sus trazas en los muros exteriores e interiores de algunas iglesias y capillas, lo que permite pensar al sistema del arte rupestre andino ya sea colonial y/o republicano como un soporte donde se están plasmando imaginarios, los que serían resultado de un largo proceso no sólo de resistencia a las imposiciones de la iglesia oficial; sino que de valores sociales y culturales anclados en memorias antiguas, pero también en el presente de la colonialidad. En este sentido, pasan a configurarse como imaginarios alternativos a la dominación religiosa católica, con representaciones que anclan en tiempos presentes y en diálogo con las imposiciones. Las iglesias fueron lugares donde las gentes andinas desafiaron los controles y vigilancias; $y$ fueron vividas, pese a las prescripciones, como recintos cuyos usos anclaban en sus propias prácticas culturales. Las iglesias siguieron siendo los espacios de las indecencias andinas que reclamaban los hispanos, permaneciendo como espacios, leídos por los andinos, como sacros, rituales y propiciadores.

En los muros se inscriben marcas andinas, constituyéndose las paredes de las iglesias en campos representacionales de valores ¿representativos para sus ejecutantes, pero también para quienes observan esos motivos pintados? ¿Sería posible pensar que esos significantes, algunos de ellos también situados en paneles rocosos, son los aceptados, los reconocidos en el nuevo contexto comunicacional andino colonial y/o republicano?

Desde ese marco de referencia las prácticas visuales que observamos en las distintas iglesias mencionadas a lo largo de este texto no solo representan actos de inscripción de significantes, sino que responden a elecciones para significar o decir algo y donde presenciarlos y "leerlos" acontece en un ámbito de multisensorialidad. Las paredes de las iglesias están siendo utilizadas para comunicar algo utilizando códigos discretos que se repiten. En las iglesias de Chuquinga y Tolapampa, los motivos fitomorfos y de camélidos; en la de Huayllaripa, fitomorfos, camélidos y antropomorfos. En las de Lagunas, y Markachavi motivos de iglesias, cruces, antropomorfos y camélidos. Por otra parte, no deja de ser significativo que algunas iglesias, como las de Yauri y Tolapampa, estaban ya construidas y en funcionamiento durante los movimientos insurreccionales de amarus y cataristas, señalándose que por allí pasaron sus tropas marcadas con distintivos de "buenos cristianos".

Es importante confirmar, al cerrar esta discusión, la persistencia de este sistema prácticamente hasta la actualidad. En la iglesia de Llallagua, en el departamento de Potosí, cerca de su límite oeste, colindante con Oruro, en las paredes interiores de una capilla menor se observa un importante despliegue de motivos antropomorfos, zoomorfos y otros, que evocan con claridad la persistencia de un sistema de representación que, en tanto técnica y configuración, es similar al del arte rupestre colonial. Corresponden a motivos en pintura areal y lineal de color rojo que representan bailes y arquitectura religiosa, procesiones, marchas y enfrentamientos militares, además de una representación antropomorfa femenina a tamaño natural en uno de sus muros laterales (figs. 15 y 16). También se observan jinetes y en menor proporción camélidos y camiones. Estos últimos podrían estar funcionando como imágenes de alasitas. Otra evidencia que reafirma nuestro supuesto de un despliegue visual, a partir de convenciones culturales propias, es la presencia en el atrio de la capilla, de un monolito huanca, que en forma evidente se encuentra reemplazando a una cruz de atrio (fig. 17).

El tránsito de las imágenes votivas de alasitas puede estar funcionando en una lógica rupestre, cuando observamos la disposición de vehículos motorizados en el arte rupestre de Chirapaca (La Paz, Bolivia. Ver Taboada 2011) o como las representaciones de camiones en el sitio de Huancarumana (Cuzco, Perú. Fig. 18) manifestaciones que han llevado a proponer la existencia de un arte rupestre republicano (Querejazu [ed.] 1992; Hostnig 2004). Frente a estos despliegues visuales en el soporte rupestre y en muros de capillas e iglesias rurales del sur andino, no podemos pensar sino en la persistencia de un lenguaje visual propio, y que se despliega contemporáneamente en la capilla de velas del templo de Copacabana (La Paz, Bolivia), y también a más de 400 $\mathrm{km}$ al norte, en el santuario de Qoyllurit'i (Cuzco, Perú). En efecto, tanto en la capilla de velas de Copacabana como en el santuario del Qoyllurit'i, ejecutores andinos 


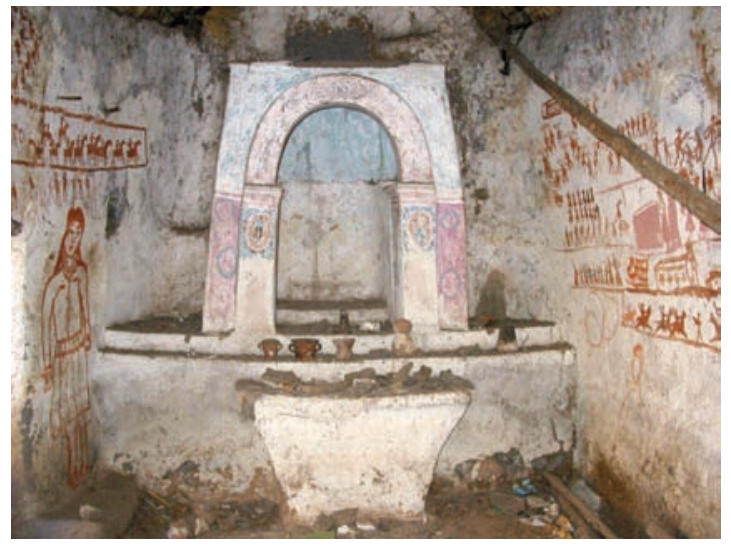

Figura 15. Interior de la capilla de Llallagua, Potosí, Bolivia (fotografía gentileza de R. Hostnig). Figure 15. Interior view of the chapel of Llallagua, Potosi, Bolivia (photo courtesy of R. Hostnig).

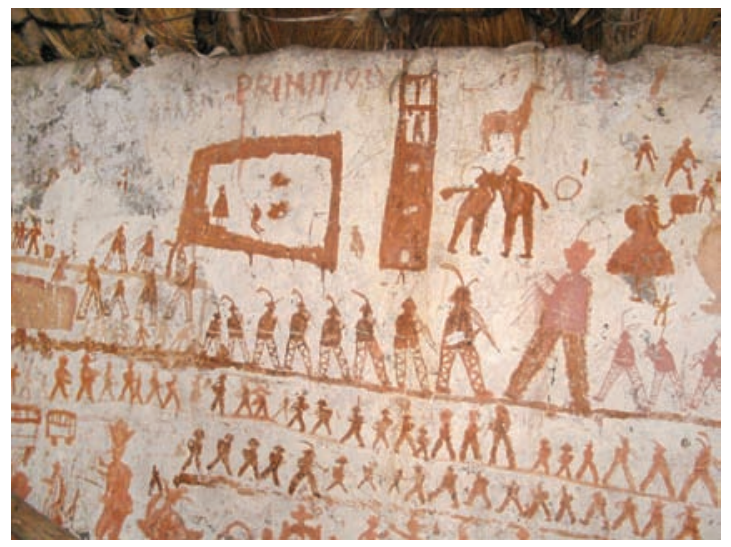

Figura 16. Muro interior de la capilla de Llallagua, Potosí, Bolivia. Se observan marchas y procesiones, la representación de una arquitectura de iglesia, y otros significantes (fotografía gentileza de R. Hostnig). Figure 16. Interior wall of the chapel of Llallagua, Potosi, Bolivia. Note the marches and processions, a church and other signifiers (photo courtesy of R. Hostnig).

contemporáneos siguen desplegando imágenes votivas (sensu Van Kessel 1976), ya desprovistas de su dimensión política como una de las características del antiguo sistema de representación rupestre de los Andes. Hoy día en estos espacios, los devotos encienden sus ofrendas de velas, las cuales se consumen en el ejercicio de la oración. Con la cera derretida y con la simple ayuda de sus dedos o cualquier otro objeto improvisado, dibujan en las paredes imágenes de "corazones", casas, vehículos, nombres y/o letras, en un gesto ritual de ruego por la prosperidad material y afectiva (figs. 19 y 20).

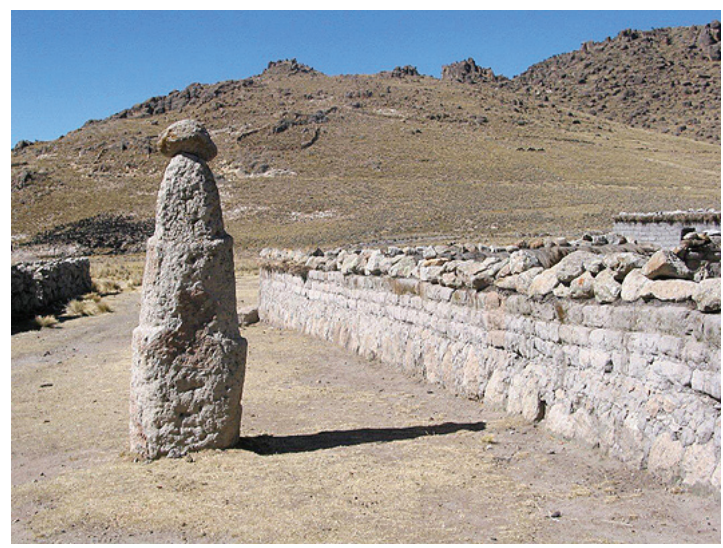

Figura 17. Vista de monolito huanca en el atrio de la capilla de Llallagua, Potosí, Bolivia (fotografía gentileza de R. Hostnig). Figure 17. View of the huanca monolith in the atrium of the chapel of Llallagua, Potosi, Bolivia (photo courtesy of R. Hostnig).

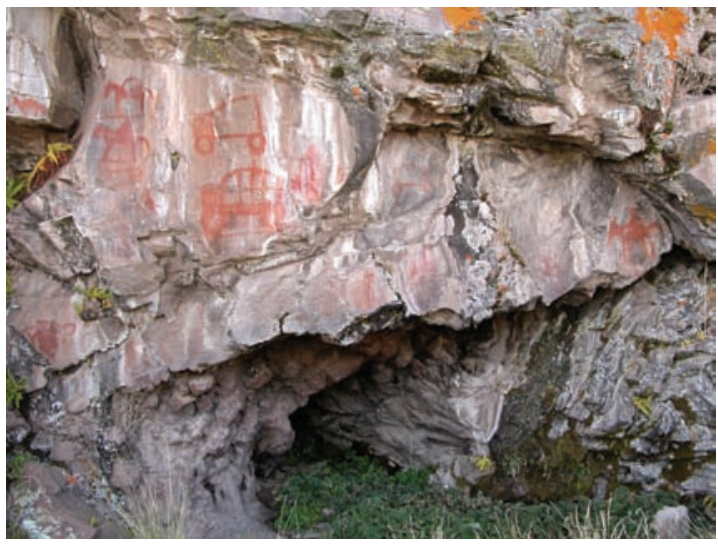

Figura 18. Arte rupestre republicano en el sitio de Huancarumana, provincia Espinar, Cuzco (fotografía gentileza de R. Hostnig). Figure 18. Rock art from the Republican period at Huancarumana site, Espinar province, Cuzco (photo courtesy of R. Hostnig).

RECONOCIMIENTOS Queremos agradecer a nuestros colegas del proyecto FONDECYT N ${ }^{\circ} 1130431$, especialmente a José Luis Martínez, por su mirada atenta en el proceso de nuestra reflexión. Además de las observaciones del arqueólogo Axel Nielsen, cuando este escrito aún estaba en una fase muy preliminar. Al padre Gabriel Antequera de la parroquia de Curahuara de Carangas, Bolivia, por sus comentarios y facilitarnos la toma de fotografías al interior de la iglesia de Curahuara De modo particular, agradecemos al investigador Rainer Hostnig, por el material visual de distintos sitios de Perú y Bolivia facilitado para la presente discusión, algunos de los cuales tuvimos la oportunidad de reconocer en terreno. También queremos dar las gracias a Vera Tyuleneva por el material visual del santuario de Qoyllurit’i en Perú. Finalmente agradecemos a los evaluadores de este artículo por sus comentarios, observaciones, discrepancias y sugerencias. 


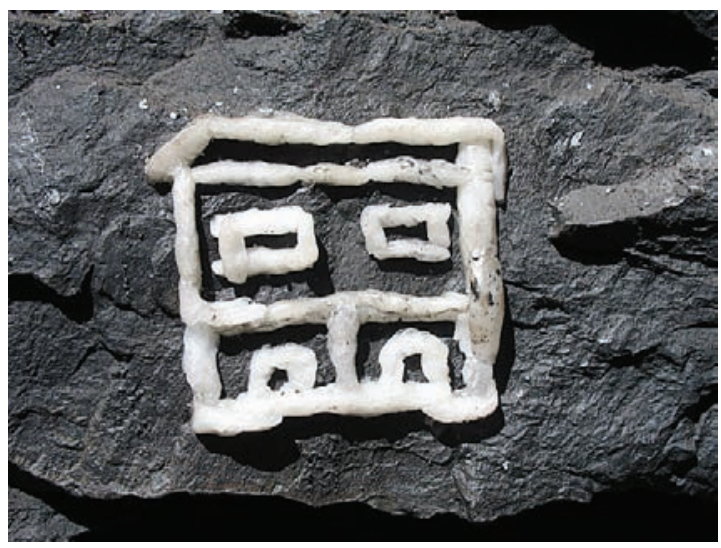

Figura 19. Capilla de velas del santuario de Copacabana, Bolivia. Imagen votiva en cera de vela (fotografía de M. Arenas). Figure 19. Candle chapel in the Basilica of Copacabana, Bolivia. Votive image in candlewax (photo by M. Arenas).

\section{NOTAS}

${ }^{1}$ En otro trabajo de uno de los autores, relacionado con el arte rupestre de Q'urini (ver Arenas et al. 2015) y Qilqata Jaliri, en el territorio Carangas del departamento de Oruro, se ha descrito un significante rupestre antropomorfo que hemos denominado "el caminante", y cuyos atributos formales son evocados contemporáneamente con la danza del awki awki en Bolivia, lo que nos lleva a pensar en la posibilidad de la construcción colonial de una agencia social que vinculaba comunidades y espacios andinos más allá del ámbito caravanero, al modo por ejemplo de los yatiris kallawallas documentados etnográficamente.

${ }^{2}$ Para la discusión de un "movimiento visual" que llamamos de apropiación selectiva ver Arenas \& Odone 2015.

${ }^{3}$ Esta información se encuentra disponible en el portal del Ministerio de Comercio Exterior y de Turismo del Perú como parte de la Ficha de Recopilación de Datos para información del Inventario de Recursos Turísticos. Disponible en: http://www.mincetur.gob.pe/ inventario/Rp_FichaAtrac.asp?pc_CodMar=2694\&pc_ubi=080000 [citado 20 junio 2015].

${ }^{4}$ Valcárcel (1947: 85) señala que en Yauri también estaba el cacicazgo de Eugenio Sinanyuca, protegido del corregidor Arriaga; fue hecho prisionero por Túpac Amaru, huyendo al poco tiempo del lugar. Este autor reconoce a Francisco Wambo Túpac como indio de Yauri, que apoya a Túpac Amaru, junto a Diego Meza, mestizo también del pueblo de Yauri.

${ }^{5} \mathrm{La}$ insurrección comenzó en la provincia de los Canas y Canchis, alcanzando amplios territorios, como las provincias de Quispicanchis, Paruro, Chumbivilcas, Lampa, Azángaro, Carabaya, Puno, Chucuito, Oruro y sus contornos, considerándose además que Túpac Amaru era arriero, lo que le habría permitido contar con amplias vinculaciones con autoridades étnicas locales a lo largo de los territorios unidos por la ruta Cuzco-Potosí, además de lazos de parentesco y compadrazgo, los que le habría permitido contar con víveres y gentes (Valcárcel 1947; O’Phelan 1979).

${ }^{6}$ Situación que no parece ser tan clara, puesto que se informa que Francisco Hallasa, cacique principal de Coroma, descendiente de

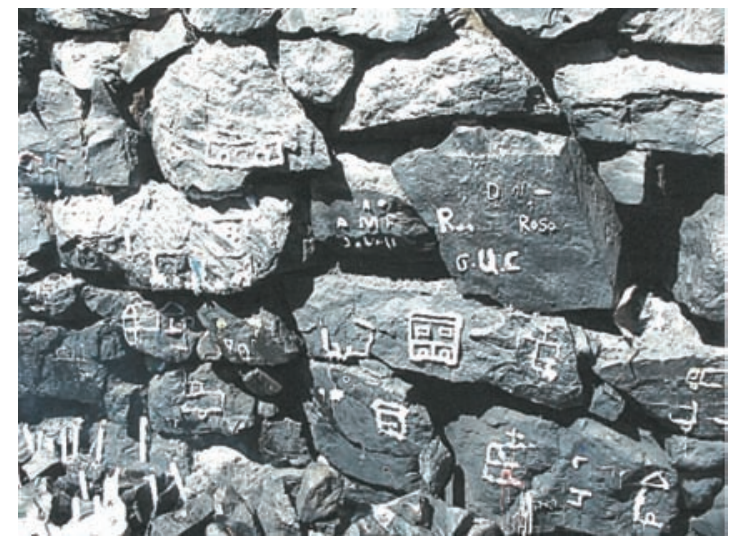

Figura 20. Representaciones votivas en cera de vela en el santuario de Qoyllurit'i, Perú (fotografía gentileza de V. Tyuleneva). Figure 20. Votive images in candle wax in the sanctuary of Qoyllurit'i, Peru (photo courtesy of $V$. Tyuleneva).

Bernabé Hallasa, reconoce que el pueblo de reducción de San Francisco de Coroma estaba conformado por la parcialidad de Cirovayos (Bubba 1997: 380).

${ }^{7}$ Para una nueva mirada sobre las dinámicas de poder inka en Carangas y Quillacas ver Lima 2014.

${ }^{8}$ La arqueóloga chilena Marcela Sepúlveda sugiere que se estarían utilizando óxidos minerales (comunicación personal, 2014)

\section{REFERENCIAS}

Anónimo, 2003 [1781]. Relación histórica de los sucesos de la rebelión de José Gabriel Túpac Amaru, en las provincias del Perú, el año de 1780. Alicante: Universidad de Alicante.

ANTequera, G., 2013. Capilla Sixtina del altiplano boliviano: 1608-2013. Cochabamba: Parroquia de Santiago de Curahuara de Carangas.

Arenas, M., 2013. Significantes rupestres coloniales del sitio Toro Muerto (Chile): Canon descriptivo y comentario preliminar. Boletín de la Sociedad de Investigación del Arte Rupestre de Bolivia 27: 87-104.

Arenas, M.; P. Lima, C. Tocornal \& L. Alvarado, 2015. El arte rupestre de Q'urini, Oruro, Bolivia. Estudio preliminar. Boletín de la Sociedad de Investigación del Arte Rupestre de Bolivia 29: 28-50.

Arenas, M., \& Odone, M. C., 2015. Cruz en la piedra. Apropiación selectiva, construcción y circulación de una imagen cristiana en el arte rupestre andino colonial. Estudios Atacameños 51: 137-151.

Arze, S., 2013. Pintura mural en iglesias del altiplano de La Paz. En Iglesias y fiestas en el altiplano de La Paz y Oruro. Aproximaciones multidisciplinarias, MUSEF, Ed., pp. 51-69. La Paz: MUSEF.

Berenguer, J., 2004. Cinco milenios de arte rupestre en los Andes atacameños: Imágenes para lo humano, imágenes para lo divino. Boletín del Museo Chileno de Arte Precolombino 9: 75-108.

BERENGUER, J., 2013. Unkus ajedrezados en el arte rupestre del sur del Tawantinsuyu: ¿La estrecha camiseta de la nueva servidumbre? En Las tierras altas del área centro sur andina entre el $1000 \mathrm{y} \mathrm{el}$ 1600 d.C., M. E. Albeck, M. Ruiz \& M. B. Cremonte, Eds., pp. 311-352. San Salvador de Jujuy: EdiUNJu. 
BubBa, C., 1997. Los rituales a los vestidos de Maria Titiqhawa, Juana Palla y otros fundadores de los ayllos de Coroma. En Saberes y memorias en los Andes. In Memoriam Thierry Saignes, T. BouysseCassagne, Ed., pp. 377-400. Lima: Éditions de l'IHEAL.

Castro, N., J. Chacama \& R. Mir, 2009. Excitar y subyugar. Pastoral de la imagen y poblaciones indígenas en Arica colonial. Dialogo Andino 34: 25-143.

Cereceda, V., 1990. A propósito de los colores de un pájaro... Boletín del Museo Chileno de Arte Precolombino 4: 57-104.

Comité ARquidiocesano del Bicentenario Túpac AMARU, 1983. Túpac Amaru y la iglesia. Antología. Colección de Documentos. Lima: EDUBANCO.

Corti, P.; F. Guzmán \& M. Pereira, 2010a. El Juicio Final de Parinacota. En Entre cielos e infiernos. Memorias del v Encuentro Internacional sobre Barroco, pp. 115-124. La Paz: Fundación Visión Cultural.

Corti, P.; F. Guzmán \& M. Pereira, 2010b. La pintura mural de la Iglesia de Santiago de Curahuara de Carangas como patrón iconográfico de la Iglesia de la Natividad de Parinacota. En Entre cielos e infiernos. Memorias del v Encuentro Internacional sobre Barroco, pp. 125-132. La Paz: Fundación Visión Cultural.

Corti, P.; F. Guzmán \& M. Pereira, 2013. La pintura mural de Parinacota, en el último bofedal de la ruta de La Plata. Arica: Fundación Altiplano, Universidad Adolfo Ibáñez.

Chacama, J.; L. Briones \& G. Espinoza, 1988-1989. El arte mural en las iglesias coloniales de la primera región y la tradición pictórica andina en el extremo norte de Chile. Diálogo Andino 7-8: 102-120.

CHACAma, J., 2009. Imágenes y palabras, dos textos para un discurso: La prédica pastoral en los Andes coloniales. Doctrina de Codpa (Altos de Arica), siglo xvinI. Diálogo Andino 33: 7-27.

Flores, J.; E. Kuon \& R. SAmaneZ, 1991. De la evangelización al incanismo. La pintura mural del sur andino. Histórica XV (2): 165-203.

Gallardo, F., 2005. Notas sobre la construcción de la imagen en el arte rupestre. Boletín de la Sociedad Chilena de Arqueología 38: 45-51.

Gallardo, F.; V. Castro \& P. Miranda, 1990. Jinetes sagrados en el desierto de Atacama. Un estudio de arte rupestre andino. Boletín del Museo Chileno de Arte Precolombino 4: 27-56.

Gisbert, T. \& A. Mesa, 2010. Los grabados, el Juicio Final y la idolatría indígena en el mundo andino. En Entre cielos e infiernos. Memorias del v Encuentro Internacional sobre Barroco, pp. 17-42. La Paz: Fundación Visión Cultural.

Gisbert, T., 1980. Iconografía y mitos indígenas en el arte. La Paz: Gisbert \& Cía. S.A. Libreros Editores.

GISBERT, T., 1998. Pintura mural en el área centro sur andina. La Paz: HISBOL.

Garcés, F. \& W. SÁnchez, 2015. Escritura andina. Pictografía e ideografía en cuero y papel. Cochabamba: Universidad Mayor de San Simón-Instituto de Investigaciones Antropológicas y Museo Arqueológico.

González, B., 2014. Discursos en el paisaje andino colonial: Reflexiones en torno a la distribución de sitios con arte rupestre colonial en Tarapacá. Diálogo Andino 44: 75-87.

GonZÁlez, P., 2015. Arte rupestre de origen Diaguita-Inka en los valles de Choapa y Limarí: Su importancia en las estrategias de interacción política inca en territorio Diaguita. En Actas del XIX Congreso Nacional de Arqueología Chilena, pp. 223-230.

GonzÁLez, R., 2004. Imágenes de dos mundos. La imaginería cristiana en la puna de Jujuy. Buenos Aires: Fundación Espigas.

Guaman Poma de Ayala, F., 1980 [1615-1616]. El primer nueva corónica y buen gobierno. Tomo II. Edición crítica de John V. Murra \& Rolena Adorno. México: Siglo xxI.
Guibovich, P. \& L. Wuffarden, 2008. Sociedad y gobierno episcopal: Las visitas del obispo Manuel de Mollinedo y Ángulo (Cuzco, 1674-1694). Lima: Instituto Francés de Estudios AndinosInstituto Riva-Agüero.

Guzmán, F., 2013. Las pinturas murales en la Doctrina de Belén Espacio Regional 1 (10): 85-96.

HernáNDEZ, M. I., 2006. Inkas y españoles a la conquista simbólica del territorio Humahuaca: Sitios, motivos rupestres y apropiación cultural del paisaje. Boletín del Museo Chileno de Arte Precolombino 11 (2): 9-34.

HidAlgo, J., 2004 [1983]. Amarus y Cataris. Aspectos mesiánicos de la rebelión indígena de 1781 en Cusco, Chayanta, La Paz y Arica. En Historia Andina de Chile, J. Hidalgo, Ed., pp. 271-295. Santiago: Editorial Universitaria.

Hostnig, R., 2003. Arte Rupestre del Perú. Inventario Nacional. Lima: CONCYTEC, UNMSM.

HostniG, R., 2004a. Registro fotográfico de las tejas pintadas del templo colonial de Chuquinga, Aymaraes, Apurimac. Informe realizado para el "Centro Hijos de Chuquinga" residentes en Lima, Perú (manuscrito en propiedad del autor).

Hostnig, R., 2004b. Arte rupestre postcolombino de la Provincia Espinar, Cusco, Perú. Boletín de la Sociedad de Investigación del Arte Rupestre de Bolivia 18: 40-64.

HostNig, R., 2006. Distribución, iconografía y funcionalidad de las pinturas rupestres de época inka en el Departamento del Cusco, Perú. Boletín de la Sociedad de Investigación del Arte Rupestre de Bolivia 20: 46-76.

Lisson, E., 1943. Colección de documentos para la historia de la Iglesia en el Perú. Apéndice $1^{\circ}$ al Catálogo de documentos del siglo Xvi Sevilla: Archivo General de Indias.

Lima, P., 2014, La presencia inka y su relación con las poblaciones locales en la región occidental de Bolivia: Los casos de Carangas y Quillacas, Oruro. En Ocupación inka y dinámicas regionales en los Andes (Siglos $x V$ y XVII), C. Rivera, Ed., pp. 45-66. La Paz: IfEA-Plural.

Macera, P., 1981. Arte y lucha social: Los murales de Ambaná (Bolivia). Allpanchis XV (17-18): 23-40.

MaldonAdo, A. \& V. EstaCio, 2012. Las primeras mitas del Apurímac al servicio de las minas de Catrovirreyna 1591-1599. Lima: Ángel Maldonado \& Venancio Estacio.

Martínez, J. L., 2009. Registros andinos al margen de la escritura: El arte rupestre colonial. Boletín del Museo Chileno de Arte Precolombino 14 (1): 9-35.

Martínez, J. L., 2012. El virrey Toledo y el control de las voces andinas coloniales. Colonial Latin American Review 21 (2): 175-208.

Martínez, J. L. \& M. Arenas, 2009. Problematizaciones en torno al arte rupestre colonial en las áreas centro sur y meridional andina. En Crónicas sobre la piedra. Arte Rupestre de Las Américas, M. Sepúlveda, L. Briones \& J. Chacama, Eds., pp. 129-140. Arica: Ediciones Universidad de Tarapacá.

Medinacelli, X., 2010. Sariri. Los llameros y la construcción de la sociedad colonial. La Paz: IFEA-Plural-ASDI IEB.

MedinacelLi, X., 2013. Pintura mural y santos patronos en las capillas de Oruro. En Iglesias y fiestas en el altiplano de La Paz y Oruro. Aproximaciones multidisciplinarias. MUSEF, Ed., pp. 71-96. La Paz: MUSEF.

Medinacelli, X. \& L. Uchanier, 2012. Arquitectura y paisaje en los santuarios de Carangas. En Turco Marka. Hombres, dioses y paisaje en la historia de un pueblo orureño, X. Medinacelli, Ed. pp. 215-285. La Paz: Instituto de Estudios Bolivianos-Fundación Cultural Banco Central de Bolivia. 
Mege, P., 2000. Originales contra la fuerza. Boletín de la Sociedad Chilena de Arqueología 30: 41-46.

Mege, P. \& F. Gallardo, 2005. Soluciones semióticas y pinturas rupestres en la localidad del río Salado (desierto de Atacama, norte de Chile). Manuscrito en propiedad de los autores.

Mesa, J., \& T. Gisbert, 1962. Las iglesias de Oruro. La Paz: Biblioteca de Arte y Cultura Boliviana, Dirección Nacional de Informaciones de la Presidencia de la República.

Mesa, J., \& T. Gisbert, 1977. Monumentos de Bolivia. La Paz: Ed. Gisbert.

Muelle, J., 1969. Las Cuevas y Pinturas de Toquepala. Mesa Redonda de Ciencias Prehistóricas y Antropológicas. Tomo 2: 186-196. Lima: PUCP, Instituto Riva-Agüero,-Seminario de Antropología.

O’Phelan, S., 1979. La rebelión de Túpac Amaru: Organización interna, dirigencia y alianzas. Histórica III (2): 89-121.

O’Phelan, S., 1995. La gran rebelión en los Andes. De Túpac Amaru a Túpac Catari. Cuzco: Centro de Estudios Regionales Andinos Bartolomé de las Casas.

Platt, T., 1996. Los guerreros de Cristo. Cofradías, misa solar y guerra regenerativa. La Paz: ASUR-Plural.

Querejazu, R., 1992. Arte rupestre colonial y republicano de Bolivia y países vecinos. Contribuciones al estudio del arte rupestre sudamericano 3. La Paz: Sociedad de Investigación del Arte Rupestre de Bolivia.

Raimondi, A., 1887. Minas de oro del Perú. Boletín de la Sociedad Nacional de Minería, octubre 15 de 1887: 745-748.

SAIGNES, T., 1986. En busca del poblamiento étnico de los Andes Bolivianos (siglos xv y xvi). Avances de Investigación 3: 5-46.

SAnhueZA, C., 1992. Tráfico caravanero y arriería colonial en el siglo XVI. Estudios Atacameños 10: 173-187.

SepúlvedA, M., 2004. Esquemas visuales y emplazamiento de las representaciones rupestres de camélidos del Loa Superior en tiempos incaicos. ¿Una nueva estrategia de incorporación de este territorio al Tawantinsuyu?". Chungara 36 (2): 437-449.

SepúlvedA, M., 2008. Arte rupestre en tiempos incaicos: Nuevos elementos para una vieja discusión. En Lenguajes visuales de los Incas, P. González \& T. L. Bray, Eds., pp. 111-123. Oxford: BAR International Series 1848.
Sinclaire, C., 1999. Pinturas rupestres y textiles formativos en la región atacameña. Estudios Atacameños 14: 327-338.

Strecker, R. \& TABoAdA, F., 1992. Escritura pictográfica y arte rupestre aymara. En Contribuciones al Estudio del Arte Rupestre Sudamericano 3, R. Querejazu, Ed., pp. 103-110. La Paz: Sociedad de Investigación del Arte Rupestre de Bolivia.

SzemiÑski, J., 1974. La insurrección de Túpac Amaru: ¿Guerra de independencia o revolución? Estudios Latinoamericanos 2: 9-60. Varsovia: Academia de Ciencias, Instituto de Historia.

TABOADA, F., 1988. Arte Rupestre de Chirapaca. Boletín de la Sociedad de Investigación de Arte Rupestre de Bolivia 2: 29-36.

TAвоAdA, F., 1992. El Arte Rupestre Indígena de Chirapaca, Depto. de La Paz, Bolivia. En Contribuciones al Estudio del Arte Rupestre Sudamericano 3, R. Querejazu, Ed., pp. 111-117. La Paz: Sociedad de Investigación del Arte Rupestre de Bolivia.

TABOADA, F., 2011. Chirapaca: Reflexiones a partir del mejoramiento de las imágenes fotográficas. Boletín de la Sociedad de Investigación de Arte Rupestre de Bolivia 25: 65-70.

Troncoso, A., 2004. El arte de la dominación: Arte rupestre y paisaje durante el período incaico en la cuenca superior del río Aconcagua. Chungara 36 (2): 453-461. Arica: Universidad de Tarapacá.

VAlCÁrCel, L., 1947. La rebelión de Túpac Amaru. México DF: Fondo de Cultura Económica.

VAN KeSSEL, J., 1976. La pictografía rupestre como imagen votiva (un intento de interpretación antropológica). En Homenaje al Dr. G. Le Paige. Antofagasta: Universidad del Norte.

VARgas, R. 1951. Concilios Limenses (1551-1772), tomo I. Lima: Imprimatur.

VARGAS, R. 1952. Concilios Limenses (1551-1772), tomo II. Lima: Imprimatur.

VÁZqUEZ DE EsPINOSA, A., 1948 [1628-1629]. Compendio y descripción de las Indias Occidentales. Washington: The Smithsonian Institution.

Vilches, F. \& M. URibe, 1999. Grabados y pinturas del arte rupestre tardío de Caspana. Estudios Atacameños 18: 73-87.

WALKer, C., 2014. The Tupac Amaru rebellion. London: The Belknap Press of Harvad University Press. 